\title{
DÜBLIN
}

Technological University Dublin

ARROW@TU Dublin

2007-01-01

\section{Webs of Power: Multiple Ownership in Tourism Destinations}

\author{
Ziene Mottiar \\ Technological University Dublin, ziene.mottiar@tudublin.ie \\ Hazel Tucker \\ University of Otago
}

Follow this and additional works at: https://arrow.tudublin.ie/tfschhmtart

Part of the Entrepreneurial and Small Business Operations Commons, Human Geography Commons, and the Sociology Commons

\section{Recommended Citation \\ Mottiar, Ziene and Tucker, Hazel: Webs of Power: Multiple Ownership in Tourism Destinations. Current Issues in Tourism, Vol.10, no. 4, pp.279-295. doi:10.2167//cit288}

This Article is brought to you for free and open access by the School of Tourism \& Hospitality Management at ARROW@TU Dublin. It has been accepted for inclusion in Articles by an authorized administrator of ARROW@TU Dublin. For more information, please contact arrow.admin@tudublin.ie, aisling.coyne@tudublin.ie, gerard.connolly@tudublin.ie.

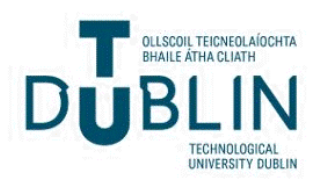




\section{Webs of Power: multiple ownership in tourism destinations}

Dr. Ziene Mottiar, School of Hospitality Management and Tourism, Dublin Institute of Technology, Cathal Brugha St. Dublin 1, Ireland

Dr. Hazel Tucker, Department of Tourism, University of Otago, PO Box 56, Dunedin, New Zealand

Short title: Webs of Power: multiple ownership

Contact Author: Hazel Tucker e-mail

Words: 8624 
Webs of Power: multiple ownership in tourism destinations 


\begin{abstract}
It has been widely noted in the tourism small business literature that collaboration between groups of businesses operating within clusters contributes both to business development and the success of destinations and regions. This paper aims to contribute to the research on tourism destination networks by focusing on multiple ownership, or portfolio entrepreneurship, when more than one small or micro business within a specific destination are owned by the same entrepreneur. Courtown, in Ireland and Göreme in Turkey are presented as two case studies in which the existence of multiple owners was identified. The implications of multiple ownership on tourism operation in these two destinations are examined taking, firstly, a supply side approach in studying the effect on the firms and products in the area of Courtown. Secondly, a demand side approach is taken by assessing the implications of multiple ownership for tourists in Göreme. Factors considered include implications for inter-firm co-operation in the area, barriers to entry for potential firms and the tourist experience. It is concluded that the practice of multiple ownership creates webs of power which embroil tourists and significantly impact on the business structure and operation of the tourism destination.
\end{abstract}

Key Words: Tourism SMEs, multiple owners, cross-national case studies, Courtown, Ireland, Göreme, Turkey 


\section{Introduction}

Network and agglomeration theories have challenged researchers not only to look beyond the boundaries of individual firms but to observe firms in a sectoral or geographical manner, investigating the interaction between firms rather than just focussing on the internal workings of an enterprise. Indeed the observation of groups of firms is an approach which is in keeping with the trends of mergers and acquisitions, and an increasing amount of networking and co-operation which have been identified throughout the tourism sectors in many nations. It has become widely accepted that small enterprises operating in clusters, and entrepreneurs working in both formal and informal networks, generally do better than those operating individually (Van Dijk \& Sandee, 2002). Within tourism this is particularly relevant as groups of enterprises and other organisations cluster together to form a destination context (Pavlovich 2003). It has been widely noted in the tourism small business literature that collaboration between groups of businesses operating within clusters contributes both to business development and the success of destinations and regions (Morrison 1998; Lynch, Halco, Johns and Buick 2000; Tinsley and Lynch 2001; Huybers and Bennett 2003; Hall 2004; Petrillo and Swarbrooke 2005).

This paper aims to contribute to the research on tourism destination clusters and networks by focusing on one specific form of practice which occurs when more than 
one small or micro business within a specific destination are owned by the same entrepreneur. This practice is known in the small business literature as multiple ownership or portfolio entrepreneurship. Within that literature, multiple ownership has been conceptualised as a lateral growth strategy (Scott and Rosa 1996; Carter 1998; Rosa and Scott 1999; Westhead and Wright 1998; Carter and Ram 2003). Rosa and Scott (1999), moreover, found that clusters of businesses connected to a single entrepreneur tended to have much lower failure rates. They therefore argued that business success should be assessed at the level of the individual entrepreneur rather than at the level of the firm. At the individual entrepreneur level then, multiple ownership represents a method for an entrepreneur to both 'grow' and to 'diversify', whilst still keeping each individual enterprise at a small or micro level. Unlike larger firms, small businesses tend to be unsuccessful if they attempt to diversify (Webster 1998). The reasoning for this is that, because of their 'smallness', each individual small firm does better if it sticks with its one main line. Multiple ownership thus allows entrepreneurs both to diversify and to spread risk across multiple firms. It also allows them to retain the 'small' character of each individual firm. The small character of firms has been shown to have a good 'fit' with new niche forms of tourism, providing local ambience and a vernacular quality to visitor experience (Morrison \& Teixeira, 2004; Middleton \& Clarke, 2001; Ateljevic \& Doorne, 2000). Thus, ownership of multiple small or micro firms is an avenue for growth in an environment where individual firm growth does not have a correlation with business success. 
Concurrently, however, multiple ownership would inevitably create a form of network or clustering which is comprised of particular power relationships between individual firms and between groups of firms. Whilst an increasing amount of research has looked at networks and clustering within tourism, the implications of multiple ownership within these forms have not been examined. Based on case-study research, this paper asks what the implications are of this specific form of business practice for tourism operation in the destination. The paper addresses this question by drawing together empirical research on two quite distinct case study destinations Courtown, Ireland and Göreme, Turkey. The discussion of the Courtown case study focuses on the implications of multiple ownership from a supply-side perspective, looking at issues of co-operation and competition and the effect of multiple ownership on the product mix. The purpose of the case-study of Göreme village in Turkey is then to consider the demand side, looking at the implications of multiple ownership 'webs of business' for tourist experience in that particular destination. By pulling together these two case study areas and by assessing the implications of multiple ownership from both the supply side and the demand side perspective, this paper provides a thorough examination of the issues.

Before presenting the case study material, it is useful to outline the tourism small business literature that considers more generally the implications of networks and clustering regarding tourism operation. 


\section{The role of tourism destination networks}

Research which has looked more generally at how small firms contribute to destination development, competitiveness and sustainability has particularly focused on tourism small firms in a 'rural tourism' context (Hall, 2004; Keen, 2004; Komppula, 2004; Tucker, 2003b). At the destination or regional policy level, tourism is increasingly seen as a useful tool for rural restructuring and development. Consequently, the opening of small businesses related to tourism, such as farms diversifying and starting to operate as farm-stays, is a widespread response. From a destination development and operation point of view, the role of tourism firms has often been understated (Mottiar and Ryan, forthcoming). There is however a growing number of case studies which show how small tourism firms and entrepreneurs can make a significant impact on the development and operation of a destination. A good example is the work by Scott and Laws (2004) who document the role of a number of small firms in the evolution of Hervey Bay, Australia as a whale watching destination. Similarly, Johns and Mattsson (2005) focus on the impact that a single individual can have, noting the development of Hay-on-Wye as a destination as a direct result of the activities of one local second hand bookshop entrepreneur.

Both at the level of the individual firm and at the destination level, however, the literature has identified collaboration and networking between groups of firms as contributing most significantly to development and growth. For example, Hall's (2004) research into wine and food tourism's role in the re-development of rural areas 
of New Zealand looks at the issue of networking and the ways in which collaboration between small firms operating in the same geographical region works to the mutual economic benefit of all participants. Similarly, Mottiar and Ryan (forthcoming), taking an industrial district approach, show how the tourism firms in Killarney have had a significant impact on the development of this destination via their co-operation and the existence of a social milieu. Indeed, with small firm management tending to be highly personalised with owner-operators developing firms using personal capital (Dewhurst and Horobin 1998; Hall and Rusher 2004), it is understandable that some collaboration and sharing of resources among firms should be beneficial to the whole. It has been noted how business clusters add value to a region by driving the region's competitive advantage (for example, Seaton 1996; Hopkins 2001; Pavlovich 2003; Hall 2004).

Inter-firm relations in such clusters involve both co-operation and competition. Indeed, Hall (2004), following Rosenfeld (1997), pointed out that one of the fundamental differences between the cluster and network concepts is that whilst networks are based on cooperation, clusters involve both cooperation and competition. The tourism destination comprises multiple sectors made up of both competing and complimentary firms which together provide a comprehensive tourist experience (Pavlovich 2003). It has been previously noted, for example, that small businesses have to rely on personal networks and other interpersonal approaches for marketing, because their limited resources preclude mass marketing (Gilmore, Carson \& Grant, 2001; Morrison, 1998). However, as Huybers and Bennett (2003:582) 
argue: 'The interactions between these tourism business operators provide an example of a social dilemma of independence in the face of interdependence. Tourism operators in the region compete with each other on the basis of their individual competences. At the same time, however, they are mutually dependent and hence pursue collective benefits'. In other words, at the intra-regional level firms are competing against each other, but at the inter-regional level they are cooperating in order to maximise the destination's competitive advantage.

The issue of multiple ownership would clearly introduce an interesting new dimension into this context of the tourism destination cluster and the dynamics of cooperation and competition at work within it. Whilst there is some discussion of multiple ownership, or portfolio entrepreneurship, within the general small business literature, as noted above, the implications of multiple ownership regarding issues of intra-regional cooperation and competition have not been examined. Moreover, the issue of multiple ownership has not been discussed within the tourism context at all. This paper thus addresses this gap in the literature by considering the implications that multiple ownership might have for tourism operation at the destination level. It considers this question from the supply side by looking at how multiple ownership affects the way in which the tourism sector operates, and it addresses the demand side by considering how multiple ownership impacts on the tourist experience within a destination.

\section{Research Methods}


Previous research by both authors in the respective case study areas identified the existence of multiple ownership or portfolio entrepreneurship. That is, they cited examples of cases where multiple tourism-related businesses were owned by one entrepreneur. Both pieces of research were conducted independently from each other and were part of broader studies taking place in the two respective case study areas. For the purposes of this paper, the relevant points directly pertaining to the issue of multiple ownership of businesses have been drawn out in order to provide a comparative case study analysis for this discussion. Following is a brief description of the research methods employed in each of the two original independent research projects.

In the Göreme case long term ethnographic research was conducted over a period between 1995 and 2005. The main initial research questions addressed the change that tourism had brought about in the village, how villagers had involved themselves with tourism, and how the interactions were played out between tourists and tourism and villagers and village life (the work is published as a whole in Tucker, 2003a). The fieldwork took place during multiple periods of between one month and one year in length spent in the village. The main method employed was a combination of participant observation and semi-structured interviews with both villagers and tourists which produced comprehensive field-notes and interview transcripts. As time progressed, the researcher gained access to almost all of the tourism small businesses in the village and was able to discuss their operation with the owner-operators as well 
as being able to observe interactions between tourists and the businesses they patronised.

As with the Courtown case study, the findings relating to multiple ownership in Göreme and associated issues were serendipitous. It was found that many of the businesses had two or three owner-partners, and the partners would also have partnerships in other businesses in the village offering different tourism services. As a central focus of the observations was the interactions between villagers and tourists, the issue being drawn from this research for the purposes of this paper is the implication this multiple ownership was found to have for tourist customers and their experiences.

In the Courtown case the original research in this area was conducted in 2001 to investigate the economic and social impact of the Seaside Resort Areas Scheme which was a tax incentive scheme implemented to encourage the development of specific seaside resorts in Ireland. The results of this study were published in Mottiar and Quinn (2001). As part of this study the important role that holiday home owners had in the development of the destination was also identified and discussed in a later publication (Mottiar and Quinn (2003)). As part of these two pieces of research extensive interviews were conducted with key informants, firms, residents, tourists and holiday home owners and in this process the researcher noticed a pattern of multiple firm ownership. During February and March 2003 she returned to the site in order to investigate this issue further. Thus this article represents the interviews that were conducted specifically as 
part of this research but. this information was supplemented by the knowledge and research findings that the author had attained during previous work in the area.

There are 32 firms in the village and the objective was to speak to all of the firms. Methods used were qualitative. Firms were contacted by phone, fax and e-mail and many were contacted on numerous occasions. In some cases the owners sent responses to questions back to the researcher and in others they were completed with the researcher. In total responses were attained from nine firms. This represents a response rate of 28 percent. These firms represented a good range of firms in the village in terms of the business they are engaged in and their relative sizes.

Five entrepreneurs or entrepreneurial families own 13 of the 32 firms in the village. Identification of this fact significantly changes the firm profile of the area. It is no longer a destination dominated by small and micro firms, it is now a village in which more than a third of the enterprises are owned by five entrepreneurs. The hypothesis is that this has to have implications for the way the destination operates and inter-firm relations and that is what section five investigates.

\section{Case Study 1: Multiple ownership in Courtown - supply side analysis}

Courtown, Co. Wexford, is a traditional seaside resort on the East coast of Ireland. Tourism in this area dates back to the 1860 s when wealthy Dublin families used to get the train to Gorey and then use a horse and carriage to travel the four miles to Courtown and stay in one of the hotels. While the dominance of Dublin tourists remain, the tourist of today most often comes to stay in their own mobile home or holiday house in or around the village. This area has undergone significant changes over the last decade with firms attempting to control the type of visitor coming by caravan sites dis-allowing the sub-letting of caravans and mobile homes and no longer 
facilitating the transient holiday maker. Sites are now rented on an annual basis. Since 1997 the area has also experienced phenomenal growth in the housing stock as a result of generous tax benefits for tourist accommodation.

The firms in this area have played a significant role in the shaping of this tourism area. Many of the firms from Courtown and the nearby town of Gorey came together to form the Courtown Development Association which purchased the village woodlands that were for sale in 1990. The stated reason for purchase was to preserve this resource for the residents. However by 1995 the group were lobbying for inclusion under the Seaside Resort Areas Scheme so that they could build houses on the land which would easily sell once designated under the tax scheme. The money was then used to develop an indoor water park (Splashworld) in a bid to keep tourists in the Courtown area when the weather is bad. In this way the association of local firms has substantially impacted the development of this local area (for an analysis of these developments see Mottiar and Quinn 2001).

Approximately 32 firms are located in this tiny village which has a permanent population of 350 . They are all broadly in the tourism, hospitality and leisure sector and they include pubs, accommodation, restaurants and entertainment and retail outlets. A traditional analysis would observe the historical role of the hotels in the village; Taravie was the first hotel to open and this was followed in the 1920s by the Courtown Hotel, the Ounavarra, and the Bayview. This combined with the fact that they are the biggest employers would lead one to assume that they are the leading businesses. In fact this is not the case. A small firm analysis would emphasise the fact that the small firm nature of this local industry effects the way the firms operate, and explains the fact that the firms do not expand. However the story of this local area is more complex. While there is no doubt that the majority of firms in the area are small with most employing less than 15 people and only one employing more than 50, five entrepreneurs or entrepreneurial families own 13 of the firms in the village. This fact changes the image from many small independent units to a view of a number of webs of businesses.

The five entrepreneurial individuals and families are as follows. Entrepreneur A began running a caravan site in 1980, in 1990 he developed a bowling and restaurant facility and later in 1993 
developed a pitch and putt facility. Under the Seaside Resort Areas Scheme in the late 1990s he built a holiday home complex from which he now rents out properties. Entrepreneur B established a guesthouse in the centre of the village in 1986. He also runs a mobile home park behind the premises and has recently built a number of retail units. In 1996 entrepreneur C purchased one of the landmark businesses in the village, and developed it into a nightclub. He has also developed a lounge, bar and a fast food restaurant. This complex is one of the largest in the village employing a total of 70 staff. Entrepreneur D is not originally from Courtown but from a village about 20 kilometres away. He bought the business in 1997 and operates a take away, diner and restaurant. Entrepreneur E, who is not from Courtown but has lived here for more than twenty years developed an Amusement arcade and take away in 2000, at the peak they employ 30 people. Aside from these businesses the other notable enterprises in the locality are four hotels, a few caravan sites, an outdoor carnival style venue and an amusement arcade which has been in the village since 1973 having formerly been operated as a corner shop since the 1950s. There are also a number of small retail outlets and bed and breakfasts.

So what, on first perusal, may have appeared as a village with about 32 small tourism and hospitality firms is now identified as having some 23 entrepreneurs who run these firms. The concentration index which evaluates the level of competition in an industry is higher than one may have thought at first observation and as approximately one third of the firms in the area are owned by five entrepreneurs multiple firm ownership is apparent. What then are the implications of discovering this ownership characteristic?

\subsection{Stronger 'insider advantage'}

The first implication is that this more concentrated control means that these firms are in a better position to take advantage of local business opportunities than the traditional micro-enterprise. When a new opportunity is available multiple owners have more resources and backing to be able to undertake a new venture. They may, for example, have land holdings throughout the local area. In any local area the firms operating in the area are like 'insiders' because they have ready access to information and knowledge from which they can create opportunities. However their size may limit this potential in terms of financial resources. A multiple ownership structure means the insider advantage can be acted upon as more resources are available. In the case of Courtown this 
can be seen by investigating the impact of the Seaside Resort Areas Scheme. This tax incentive scheme provided a golden opportunity for development for anybody who had land or access to capital. Most people sold their land to developers for a significant profit. Only three cases were recorded of people who decided to risk a longer-term payout by developing their own land and then either selling the houses or operating them as tourist accommodation. Each of these three cases was a person or family who was an entrepreneur in the local area already and one was a multi firm owner. In this way the largest advantages of this opportunity were concentrated among what could be called the entrepreneurial elite.

Another example is entrepreneur B who owned a site in the village which could be developed into a retail unit. When interviewed he said that he was waiting to develop the site until he saw the impact of the opening of Splashworld. He subsequently built the unit. His insider knowledge of the possibility of this new amenity being opened (he was a member of the CDA), combined with the assets he had from the businesses that he owns, allowed him to capitalise on developments in the village by choosing the appropriate time to build his new business.

It is clear that the combination of insider knowledge and resources, or access to resources, allows multiple owners to create more wealth and increase their importance in the local economy. However the industrial structure of the area is not radically altered, as rather than the destination becoming home to a number of large firms, instead there is the emergence of new firms. The small firm nature of the area remains intact, although the internal power relations between firms in the destination may be significantly altered and more webs of power may be identified.

\section{$\underline{5.2 \text { Consequences for co-operation }}$}

The second issue is that multiple ownership affects the traditional analysis of relations between firms, which, as noted above, normally concentrate upon competitive and co-operative relations. It is notable that all firms who responded to the survey in this case study engage in some type of co-operation most often by recommending other firms in the area to tourists. In 75 percent of cases the co-operation was with firms in the Courtown area and notably 40 percent of firms cooperate with firms owned by friends and family. Concurrently, all firms categorised their main competitors as being located in Courtown. 
Multiple ownership makes the issue of co-operation murky as firms which are owned by the same entrepreneur are more likely to engage in co-operation, but this co-operation is unlikely to be termed as that. For example entrepreneur A who built the self-catering accommodation mentions the other businesses he is involved in on this website. He lists his adventure golf and bowling product on the places to visit page and under the special offers there is a special discounted rate for use of Splashworld (he was a leading player in the CDA which developed this water facility). This cross marketing is not easily defined as co-operation as it is the same owner/manager making the decision in all cases. Rather, it is simply a strategic management decision. And yet from the outside it may appear as co-operation.

By extension it may be the case that such firms are less likely to co-operate with other firms because they may not have the same need to do so. The small firm nature of industries usually implies a level of interdependence between firms as described above. However as more and more of the services and goods are controlled by one owner this interdependence begins to diminish and this can be seen by declining levels of inter-firm co-operation coupled with a concentration of power among a small number of firms in the destination.

\section{$\underline{5.3 \text { Consequences for the product mix }}$}

Thirdly the types of products developed may be influenced by this type of ownership characteristic. Owners setting up or purchasing new firms are not going to compete with themselves. Rather, they will develop products which complement or are totally distinctive from their existing products. In this way the new firms that are established, if established by existing entrepreneurs, will not increase the level of competition in the local area. This may have negative price implications but on the positive side it may result in a more varied and extensive final product for the tourist. This is apparent in the case of Courtown where, as described above, in the main the entrepreneurs have extended their business interests into complimentary goods and services. It is interesting to note that a business owner who was very much against the purchase of the woodlands and the development of Splashworld was the owner of the funfair in the village, while those who were most actively involved in the development of Splashworld were primarily in the accommodation sector. 


\section{$\underline{5.4 \text { Consequences for local business groupings }}$}

Business groupings and associations may be more easily created and operated with only a few members who dominate the local business community. These individuals can have status due to the fact that they own a number of firms and their opinion can be given extra credence as it counts for a bigger proportion of the businesses in the area. In the case of the CDA there were two apparent leaders of this group, both of whom were multiple owners in the village. They were the drivers in establishing the group in the first instance and also in terms of lobbying effectively to have Courtown included as part of the Seaside Resort Areas Scheme.

In order to ascertain whether there was a clear business leader in the area, firm owners were asked in their opinion who is the leading business person in Courtown. The name which appeared most frequently is that of entrepreneur A (in fact this was the only person who was mentioned more than once). When asked why they selected this individual most referred to the fact that he had the 'most' businesses in the area. While in some cases there was clear respect for this entrepreneur, another respondent said 'He likes to think he is into everything', and rather begrudgingly added 'I suppose he does own the most businesses'. Notably, status is conferred on those who own the most firms rather than those who own the oldest or largest.

It is interesting to note that when asked from a list of options what was important or useful to be successful in business in Courtown, all respondents said that the most important thing was to be friendly with other entrepreneurs in the area, and all but one said that being part of the sports and social clubs in the local area was important. Respondents were divided regarding the relevance of being from the area originally. These responses show the recognised importance of being part of the business and local community, and this combined with the fact that the majority of firms identify a clear local business leader, indicates a level of consensus among firms.

\section{$\underline{5.5 \text { Consequences for barriers to entry and operation }}$}

Barriers to entry are a familiar concept in the study of market structures. The idea is that sometimes there are barriers which make it difficult for new firms to enter the market. The reasons for this can be manifold including issues like branding, control of essential raw materials 
or legal barriers such as copyright issues. These are most common in monopoly or oligopoly situations when the number of firms who control the market is limited. In a small tourism destination one would not expect there to be extensive barriers to entry as all of the firms are small and none have overriding control. However the family of firms owned by one owner may have a significant amount of market share between them. As discussed above, they may be the most likely to take any new business opportunities that are available utilising their insider information. Moreover, inter-firm co-operation between existing firms may actually act as a barrier for any new potential entrants.

When asked whether Courtown was an easy place for new entrepreneurs to set up business, six respondents, a clear majority, said that it was, and those who said no referred to issues such as planning, infrastructural limitations and the short season. So it appears that there is no evidence of barriers to entry from the firm owners' point of view. Interestingly though one owner who is originally from the general area said that in the beginning [Courtown] was a closed shop but the influx of tourists had changed this... [however she noted that in general business owners in the area are] 'cautious of newcomers'. It must be noted that all but one of the respondents to the survey do not have any ambitions to establish new businesses and this may therefore taint their view on barriers to entry. Perhaps an outsider or prospective business may have a different view.

\subsection{Summary}

The supply side analysis has shown that multiple firm ownership has impacted the inter-firm relations and the way in which Courtown has developed. What seems like inter-firm co-operation may not actually be that, insider knowledge combined with resources means that emerging new firms are often part of an existing web of businesses and consequently new products are in related rather than competing areas. The power that these webs of firms have is extremely important to note as this can have positive effects in terms of acting as a driving force and creating a consensus among the broader business community but may also act as a barrier to entry. While these findings are interesting in themselves they do not inform us of the demand side implications of multiple ownership and this is what the next case study does. 
This research hypothesizes that the consequences of this type of an area in which there are multiple firm owners are The power that these multiple firm owners have has resulted in them playing an extremely important part in the development of Courtown.

ensures that they ply a significant role in the he type of products that are developed in the destination, the ease with which new firms are

\section{Case Study 2: Multiple ownership in Göreme - demand side analysis}

Göreme is situated two hundred kilometres south east of Ankara in the Cappadocia region in the centre of Turkey, and is set amongst a "moonlike" landscape of giant rock cones with historic cave dwellings and Byzantine churches. In the mid-1980s the 'Göreme Open-Air Museum', a particularly well-preserved caved monastic site, was afforded UNESCO World Heritage Site and National Park status. Two kilometres from the open-air museum, the village, or township, of Göreme is also inside the national park boundary and is consequently protected from large-scale capital investment and construction. The Ministry of Culture imposes strict regulations concerning the construction of new buildings within the national park area and the building of large hotels is not permitted. In contrast to the situation in some other towns in the Cappadocia region, therefore, Göreme's tourism has remained relatively low on capital investment, especially investment coming from outside of the village, and has developed in a pattern of small or micro businesses that are mostly locally owned.

A steadily increasing number of independent travellers, or 'backpackers', visited Göreme throughout the 1980s and 1990s. This led to many local people opening small pansiyon (small accommodation establishment, often in a family home and with fewer than ten rooms), restaurants, tour agencies and souvenir shops. Today, with a population of around 2000 permanent residents, Göreme has approximately seventy pansiyons, plus a handful of more upmarket hotels and a few camping sites. Other tourism-related businesses include: approximately fifteen tour agencies (operating 
minibus, bicycle and walking tours in the region); fifteen restaurants; five or six bar/discos; fifteen carpet shops; an English language second-hand book shop; several general stores; and numerous souvenir shops and souvenir stands (these stands are mostly situated near the entrance of the Göreme Open-Air Museum). There is also a horse ranch which runs horse-riding tours, a hot-air ballooning operation run by two pilots from northern Europe, and three car / bike rental companies.

The particular pattern of business growth has undoubtedly been affected by certain aspects of Göreme culture and social relations, as well as by the wider economic and business environment. The simple and informal character of the earlier businesses, developed in the 1980s, placed the village men in a position of 'hosts' to their tourist 'guests' (see Tucker 2003a). With fewer restaurants and tour agencies in the village at that time, pansiyons were the main centres of tourists' entertainment, and the pansiyon owners were the main providers of that entertainment; serving meals, guiding on walks and trips in their cars, and singing Turkish folk songs when the tourists gathered in the evenings. Today, while such services still prevail and tourists can still be entertained within many of the pansiyons, businesses in the villages have tended to become more specialised. With the significant number of prominent tourist restaurants and bars along the main street of the village, tourists are now more likely to go out of their pansiyon for their evening entertainment. The guiding of tourists has also become more formalised with a gradual increase in the effectiveness of laws concerning licensing and taxation. This shift has made it more difficult to run multiple services from individual businesses. For example, because tour agencies are now under the control of the national controlling body TURSAB, which legally enforces the necessity of full insurance and licensing with certified guides, pansiyon owners take legal risks if they take their guests out for a sightseeing trip in their car.

Individual entrepreneurs and entrepreneurial families owning pansiyons have consequently opened other businesses, or gone into partnership in multiple businesses, offering complementary tourism services. Many pansiyon owners, for example, own or have part ownership of a tour agency, with the primary idea that the tourists staying 
in the pansiyon will go on day tours with the linking tour agency. Similarly, some carpet shop owners have gone into partnership in a pansiyon business and sometimes also a tour agency. As well as individual entrepreneurs being owners of multiple businesses, entrepreneurial families also own various businesses. For example, one pansiyon owner set up a tour agency in partnership with one of his brothers. A third brother owns a horse stables so that the horse riding tours and other day tours are promoted and sold primarily in the pansiyon and tour agency.

Another process occurring is that many families who developed a pansiyon business in their old cave house have decided to buy a more modern home for their family and to rent out the pansiyon business, usually on a one or two year basis. Often younger men of the village who do not have significant resources of their own go into partnership in a pansiyon business for a year or two. Many have entered such a partnership with a friend who may already have part ownership in a carpet shop or a tour agency. The ownership of businesses is therefore quite fluid in that it changes year by year as entrepreneurs enter into partnerships and ties for one year, and then change one of their partnerships the following year. Multiple ownership in Göreme might thus be said to form webs of businesses, which are complex and strong while they last, but forever changing shape as links are broken and re-formed in different mutations. The analogy of a web bears significance for the tourist experience side, as will be discussed later.

\section{$\underline{\text { 6.1 Consequences for competition and co-operation }}$}

Competition tactics among Göreme businesses are openly visible and often nasty. There operates a 'culture of equality' in Göreme (see Bailey 1969, 1971 for early discussions on the culture of equality in peasant societies) whereby the villagers are constantly competing to remain equal. This paradox in small communities is explained by Bailey in the following: 'People remain equal because each one believes that every other one is trying to better him, and in his efforts to protect himself, he makes sure that no one ever gets beyond the level of approved mediocrity. Equality, in communities like these, is in fact the product of everyone's belief that everyone else is 
striving to be more than equal' (1971:19-20). This is the reason for the sometimes nasty business tactics used to break the visible success of competitors among Göreme's tourism services. Entrepreneurs will often resort to measures which will break another's success even if those measures also damage his own profits. Frequent price wars occur in Göreme during the summer months and they often reach a point where businesses are running at a loss. This occurs precisely because of the strong desire in everyone that no-one else becomes more successful than themselves.

Multiple ownership and the formation of multiple partnerships play a large part in intensifying this competitiveness because it is accepted by villagers that tourists staying in a particular pansiyon will buy day tours from the tour agency linked to that pansiyon rather than another agency. The construction of the webs of businesses serves to trap tourists into a particular business network, and thus to broaden particular entrepreneurs' chances in the business competition. However, as with the Courtown case discussed above, what may appear as an increase in inter-firm cooperation is not in fact co-operation between two or more entirely separate firms. Rather, it is one individual owner ensuring that patrons of one of his businesses also go to his other business(es) for the other services they require.

\subsection{Consequences for tourist experience}

The partnerships and webs formed between the businesses serve to strengthen the position of the villagers in relation to tourists so that the tourists staying in the village often feel embroiled in a particular business 'web' and thereby restricted in their choice concerning which particular services they patronise in the village. Villager entrepreneurs tend to have a fiercely possessive attitude towards tourists, saying, for example, "They are my tourists and no one else can have them". If the tourists do then go to another business which is in another 'web', they are behaving in a way which dishonours the relationship with their initial 'proprietor'.

Although this might appear extreme, it is made clearer when viewed via the issue of hospitality. Göreme people take pride in their "hospitable culture", and the concepts 
of misafirperverlik (hospitality) and misafir (guest) are central to villagers' discourses regarding themselves, their lives, and tourism. The issue of hospitality can nevertheless be a confusing one for both the hosts and the guests in touristic encounters. Hospitality is considered by local people to be an integral part of their traditional culture, and tourists usually receive that hospitality graciously, often discussing the great friendliness, helpfulness and hospitality in their experience in Turkey. Yet, it is a misconception that hospitality should come easiest to the guest, as it is an exchange which always places the host in a position of control over the encounter (See Berno 1999, Heal 1990, Wood 1994, Tucker 2003a, 2003b for discussion of the social exchange of hospitality). As 'guests', tourists have certain obligations placed upon them since the guest is obliged 'to accept the customary parameters of his hosts' establishment, functioning as a passive recipient of goods and services defined by the latter as part of his hospitality' (Heal 1990:192).

Pansiyons are spaces where tourists ' behaviour and attitudes can most easily be controlled by villagers. Upon tourists' arrival at a particular pansiyon, the pansiyon owner(s) proceed to endow them with hospitality, offering a free coffee or beer and inviting them on a sunset-viewing trip in the evening followed by a pansiyon barbecue complete with Turkish music and dancing. The giving and receiving of hospitality (food and drink, accommodation and entertainment) serves to engage principles of reciprocity between hosts and guests, and thus a complex set of international rules involving shared values and trust (Burgess 1982; Maus 1967; Selwyn 2000; Wood 1994). Hosts consequently hold a position of significant control over their guests, and this control emerges specifically from the social exchange of hospitality and the relationship which hence arises between the giver and the receiver. Pansiyon owners thus continue to control their visitors' stay by recommending tours and walks, as well as which restaurant, carpet shop and tour agency to patronise. The exchange of hospitality places the guest in a position of obligation to his or her host so that the tourist placed in this role is obliged to follow up particular recommendations made by the host. If the pansiyon owner does not own or have partnerships in other tourism services, he will receive a commission payment from businesses he sends customers 
to. Besides the webs of multiple ownership in Göreme, a complex commission system operates among the tourism businesses so that if no formal connection, such as joint partnerships, links two businesses that share customers, then commission payments will be made. Because of the greater gain to be had, though, the strongest recommendations or referrals are made to the owner-partners' other businesses.

Tourists often, therefore, get caught in the web of businesses owned by their pansiyon host or other members of that host's family. Of course, these invitations and adventures all serve to individualise each tourist's experience in Göreme, and so whilst tourists can feel restricted by their supposed allegiance to a particular man or group of men and their businesses, they generally enjoy the serendipitous nature of the interactions. They can, however, feel a sense of restriction, or even sheer confusion, when the exchange of hospitality means that they feel obliged to follow multiple owners' recommendations for particular tourism services.

\section{Conclusions}

In his recent edited volume on tourism small firms, Thomas (2004:1) commented that 'the depth of our knowledge of the dynamics of smaller enterprises in tourism and how they articulate with the economy and society remains relatively shallow'. This paper has contributed to addressing this problem by not only moving from an independent firm perspective to focus on the relationships between firms, but also by drawing attention to the issue of multiple firm ownership in tourism destinations. Whilst multiple ownership is a mechanism for individual entrepreneurs to grow their business portfolio within a distinctly small or even micro business environment, the two case studies presented here have shown that multiple ownership can have important consequences for tourism operation at the destination level. Not only do the Courtown and Göreme cases identify multiple ownership as a significant characteristic of small tourism business development within two distinct destinations, but they also indicate, both from the supply and the demand perspectives, that 
multiple ownership can have significant effects on the dynamics of inter firm relations and the operation and development of tourism destinations.

From a supply side, the dynamics of cooperation and competition within a destination become altogether less clear-cut when introducing multiple firm ownership into the analysis. The issue of cooperation becomes obscured in that practices such as joint marketing and recommending particular activities to tourists are not actually the result of networking cooperation between individual entrepreneurs. Moreover, particular entrepreneurs, along with their multiple businesses, become dominant in the local business environment. This then serves to create higher barriers to entry for other entrepreneurs and affects the final product offering. Issues of control, influence and power thus become highly relevant as the groupings of firms establish particular groupings or webs of power. These webs of power are not only able to exercise control over the business environment, but also over the visitors to the destination.

The Göreme case study has shown that the construction of strong webs of businesses through multiple ownership practice serves to trap tourists into a particular business network. This entrapment occurs quite intensely because of the endowment by local entrepreneurs of 'Turkish hospitality' onto their tourist guests. This places guests in a position of obligation to their entrepreneur host which then serves to strengthen that individual entrepreneur's recommendations to his other, complimentary, tourism businesses. Whilst this sense of feeling embroiled in a particular business 'web' is not necessarily a negative experience for tourists, as it is coupled with a positive experience of host-guest interaction and 'hospitality', it is nonetheless a consequence of multiple ownership which is important to consider. Moreover, it indicates that the demand side perspective or the tourist experience side of networking and clustering practices is an important area for further research.

Indeed, this research has turned the first stone in what will be an interesting discussion about multiple ownership in the tourism business context. The inductive nature of the research presented in this paper leaves plenty of scope for further research. It has 
shown not only that multiple ownership is a feature of the small business environment within tourism destinations, but that this can have significant impacts on the way the local industry operates, as well as on the experience of the tourist. Further research will perhaps investigate in more depth issues such as the power relations within and between these webs of power and the changed role of the tourist as a fly caught within these webs. As a first step in identifying multiple ownership as an important characteristic in small tourism business practice, this paper adds another angle to the growing literature on the role of small tourism firms in the development of tourism destinations.

\section{Bibliography}

Ateljevic, I. and Doorne, S., (2000) Staying within the fence: Lifestyle entrepreneurship in tourism. Journal of Sustainable Tourism, Vol. 8, No. 5: 378-392.

Bailey, F.G., (ed.) (1971) Gifts and Poison - The Politics of Reputation, Oxford: Basil Blackwell.

Bailey, F.G., (1969) Strategems and Spoils - The Social Anthropology of Politics, Oxford: Basil Blackwell.

Becattini, G. (1990) Italy. In W. Sengenberger, G. Loveman and M. Piore (eds) The re-emergence of small enterprises - industrial restructuring in industrialised countries (pp. 144-173). Geneva: International Institute for Labour Studies.

Berno, T., (1999) 'When a Guest is a guest: Cook Islanders View Tourism', Annals of Tourism Research, Vol. 26: 656-675. 
Brusco, S. (1982) The Emilian model: productive decentralisation and social Integration. Cambridge Journal of Economics 6, 167-184.

Burgess, J., (1982) Perspectives on gift exchange and hospitable behaviour, International Journal of Hospitality Management, Vol.1: 49-57.

Carter, S., (1998) 'Portfolio Entrepreneurship in the Farm Sector: Indigenous Growth in Rural Areas?', Entrepreneurship and Regional Development, Vol. 10(1): 17-32.

Carter, S., and Ram, M., (2003) 'Reassessing Portfolio Entrepreneurship', Small business Economics, vol. 21: 371-380.

Dewhurst, P. and Horobin, H. (1998) Small business owners. In R. Thomas (ed.) The Management of Small Tourism and Hospitality Firms (pp. 19-38), London: Cassell.

Gilmore, Carson and Grant (2001)

Hall, C.M. (2004) Small firms and wine and food Tourism in New Zealand: Issues of Collaboration, Clusters and Lifestyles. In R. Thomas (ed.) Small Firms in Tourism: International Perspectives (pp. 167-182), London: Elsevier.

Hall and Rusher (2004)

Heal, F., (1990) Hospitality in Early Modern England, Chicago: Clarendon Press. 
Hopkins, K., (2001) 'Regional tourism Micro-Market development: Strategic Alliances or Clusters for Competitive Advantage'. Paper in Proceedings of Entrepreneurship in Tourism and the Contexts of Experience Economy conference, 47 April 2001, Rovaniemi, Lapland, Finland.

Huybers, T. and Bennett, J., (2003) 'Inter-firm cooperation at nature-based tourism destinations', Journal of Socio-economics, Vol. 32: 571-587.

Johns, N. and Mattsson, J. (2005) Destination development through entreprenurship: a comparison of two cases, Tourism Management, Vol. 26, No. 4: 605-616.

Keen, D., (2004) The Interaction of Community and Small Tourism Businesses in rural New Zealand. In R. Thomas (ed.) Small Firms in Tourism: International Perspectives (pp.139-154), London: Elsevier.

Komppula, R. (2004) Success and Growth in Rural Tourism Micro-Businesses in Finland: Financial or Life-style Objectives? In R. Thomas (ed.) Small Firms in Tourism: International Perspectives (pp. 115-138), London: Elsevier.

Lynch, P., Halco, K., Johns, N. and Buick, I., (2000) 'Developing small business networks to build profitable tourist destinations'. Paper presented at Destination Development Conference, 13-14 September, Ostersund.

Mauss, M., (1967) The Gift, London: Routledge. 
Middleton, V. and Clarke, J., (2001) Marketing in Travel and Tourism. Oxford: ButterworthHeinemann.

Morrison, A., (1998) 'Small firm co-operative marketing in a peripheral tourism region', International Journal of Contemporary Hospitality Management, Vol. no.5: $191-7$.

Morrison, A. and Teixeira, R. M., (2004) Small Firm Performance in the Context of Agent and Structure: A Cross-Cultural Comparison in the Tourist Accommodation Sector. In R. Thomas (ed.) Small Firms in Tourism: International Perspectives (pp. 239-256), London: Elsevier.

Mottiar, Z and Ryan, T (forthcoming) The role of SMEs in Tourism development: An industrial district approach applied to Killarney, Ireland in Thomas, R. and Augustyn M. Tourism in the New Europe: Perspectives on SME Policies and Practices, London: Elsevier.

Mottiar, Z and Quinn, B. (2001) Shaping leisure/tourism places - the role of holiday home owners: a case study of Courtown, Co. Wexford, Ireland. Leisure Studies Vol. 22 No. 2 pp.109-129.

Pavlovich, K., (2003) 'The evolution and transformation of a tourism destination network: the Waitomo Cave, New Zealand', Tourism Management, Vol. 24: 203-216. 
Petrillo, C. and Swarbrooke, J., (eds) (2005) Networking and Partnerships in Destination Development and management: Proceedings of the ATLAS Annual conference 2004, ATLAS, Arnhem.

Pyke, F., Becattini, G. and Sengenberger, W. (1992) Industrial Districts and InterFirm Co-operation in Italy. Geneva: International Institute for Labour Studies.

Rosa, P. and Scott, M., (1999) 'The prevalence of Multiple Owners and Directors in the SME Sector: Implications for our Understanding of Start-up and Growth', Entrepreneurship and Regional Development, Vol. 11: 21-37.

Rosenfield, S. A., (1997) Bringing business clusters into the mainstream of economic development, European Planning Studies, Vol. 5, No. 1: 3-23.

Schmitz, H. (1993) Small shoemakers and Fordist giants: tale of a supercluster, Ids Discussion Paper 331.

Scott, M. and Rosa, P., (1996) 'Opinion: Has Firm Level Analysis Reached Its Limits? Time for a Rethink?', International Small Business Journal, Vol. 14: 81-89.

Scott, N and E. Laws (2004) Whale Watching - the Roles of Small Firms in the evolution of a New Australian Niche Market in Thomas, R Small Firms in Tourism, pp.153-167.

Seaton, A. V., (1996) 'Hay on Wye, the Mouse that Roared, Book Towns and Rural Tourism, Tourism Management, Vol. 17 (5): 379-382. 
Selwyn, T. (2000) An anthropology of hospitality. In C. Lashley and A.

Morrison(eds.), In Search of Hospitality: Theoretical Perspectives and Debates (pp.

18-36), Oxford: Butterworth-Heinemann.

Thomas, R., (2004) International Perspectives on Small Firms in Tourism: A Synthesis. In R.

Thomas (ed.) Small Firms in Tourism: International Perspectives (pp. 1-12), London: Elsevier.

Tinsley, R. and Lynch, P., (2001) 'Small tourism business networks and destination development', International Journal of Hospitality Management, Vol. 20: 367-378.

Tucker, H., (2003a) Living With Tourism: Negotiating Identities in a Turkish Village, London: Routledge.

Tucker, H., (2003b) The Host-Guest Relationship and its Implications in Rural Tourism. In D. Hall, L. Roberts and M. Mitchell (eds.) New Directions in Rural Tourism (pp. 80-89), Aldershot: Ashgate.

Van Dijk, M.P. and Sandee, H. (2002) Innovation and small enterprise development in developing countries. In M. P. Van Dijk and H. Sandee (eds.) Innovation and small enterprises in the Third World, Cheltenham: Edward Elgar.

Webster, M., (1998) Strategies for Growth. In R. Thomas (ed.) The Management of Small Tourism and Hospitality Firms (pp. 207-218), London: Cassell.

Wood, R., (1994) 'Some Theoretical Perspectives on Hospitality', in A.V. Seaton et al. (eds.), Tourism-The State of the Art, Chichester: Wiley. 
Westhead, P. and Wright, M., (1998) 'Novice, Serial and Portfolio Founders: Are They Different?', Journal of Business Venturing, Vol. 13: 173-204. 
This article has been significantly altered to take account of the comments of the reviewers. In particular:

- We have re-structured the literature section and discuss the cluster and portfolio entrepreneur literature. We then identify a clear research question: how does multiple ownership impact on inter-firm relations in a cluster and the operation and development of the destination. We believe that these changes result in a much clearer theoretical background and specific research questions which form a stronger basis for the empirical work that follows.

- The research methods section has been expanded to provide more information about how the case studies were conducted and also outlines the original pieces of research that initially identified this multiple ownership characteristic in both cases.

- Some changes have been made to the two case studies to standardise them and so make them more complementary. This makes the use of the two cases more persuasive.

- The changes in the literature section have been reflected in a re-written and stronger conclusions section.

We believe that this revised article has responded to the comments of the reviewers and the substantial re-working that has been undertaken results in a much better article which we would now like to be considered in its revised form. 